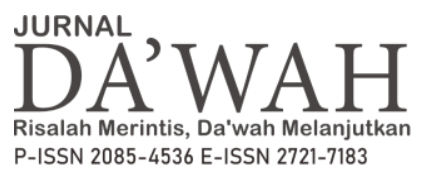

\title{
FIQIH MINORITAS MUSLIM DALAM BERINTERAKSI KEPADA NEGARANYA
}

\author{
DOI: https://doi.org/10.38214/jurnaldawahstidnatsir.v4i01.97 \\ Imam Taufik Alkhotob \\ imamtaufik@stidnatsir.ac.id \\ STID Mohammad Natsir, Indonesia
}

\begin{abstract}
When the Muslim community lives in a country as a minority, they usually stay active with limited space and movement. This is because they come with different religions and cultures. As a minority, Islam regulates how they should interact with the country where they live. Through qualitative methodology and descriptive analysis writing, the author will explain the forms of interaction that must be carried out. The result is six things; Minority Muslims are obliged to preach Islam to the Community and the State, Maintain the implementation of the main religious syari'at for individuals in the life of the state, Maintain the rules of the shari'ah that have been agreed upon regarding its halalness and prohibitions, even though the State legalizes it, Obligation to be involved in the process building the State and resolving the problems of the State, the obligation to maintain relations between fellow citizens of the State and not to carry out rebellion against the State unless they have the ability and after seeing the magnitude of the Maslahat caused
\end{abstract}

Keyword : Fiqh, Interaction, da'wah, minority

\section{PENDAHULUAN}

Asal usul terbentuknya minoritas Muslim di berbagai Negara, bereda-beda antara satu negara dengan yang lainnya. M. Ali Kettani menjelaskan ada tiga bentuk munculnya kaum minoritas Muslim;

Pertama, Suatu komunitas Muslim dijadikan tidak efektif oleh kelompok non-muslim yang menduduki wilayah komunitas Muslim, meskipun umat Islam di wilayah itu secara jumlah tergolong mayoritas. Dalam rentangan waktu yang lama karena pengaruh kependudukan oleh komunitas non-Muslim tersebut, komunitas Muslim yang tadinya secara jumlah mayoritas, berubah menjadi minoritas karena pengusiran secara 
besar-besaran oleh komunitas non-Muslim. Di sisi lain, terjadi gelombang imigran non-Muslim secara besar-besaran.

Kedua, ketika pemerintah Muslim di suatu negara tidak berlangsung cukup lama, atau usaha menyebarkan Islam tidak cukup efektif untuk mengubah Muslim menjadi mayoritas dalam jumlah di negeri-negeri yang mereka kuasai. Berbagai kekuasaan politiknya tumbang dan umat Islam mendapati dirinya turun status dari yang mayoritas menjadi minoritas dalam negerinya sendiri.

Ketiga, ketika non-Muslim di lingkungan non-Muslim pindah agama menjadi Muslim. Jika pemeluk Islam yang baru ini menyadari akan pentingnya keyakinan Islam mereka dan memberikan prioritas atas ciriciri lain, dan mencapai solidaritas sesama karena memiliki keyakinan yang sama maka terbentuklah suatu minoritas Muslim baru. Biasanya arus imigran dari muallaf menyatu untuk membentuk suatu minoritas Muslim seperti kasus yang terjadi di negara Srilangka. Di negara tersebut, umat islam merupakan penyatuan antara imigran Arab Selatan dan Muslim muallaf di Srilangka. ${ }^{1}$

\section{Mencermati Populasi Muslim di Eropa}

Peneliti Pew Research Center Conrad Hackett dan David Mcclendon menayangkan pemberitaan bahwa Christians remain world's largest religious group, but they are declining in Europe. ${ }^{2}$ Penelitan ini menyimpulkan bahwa Umat Kristen tetap menjadi kelompok agama

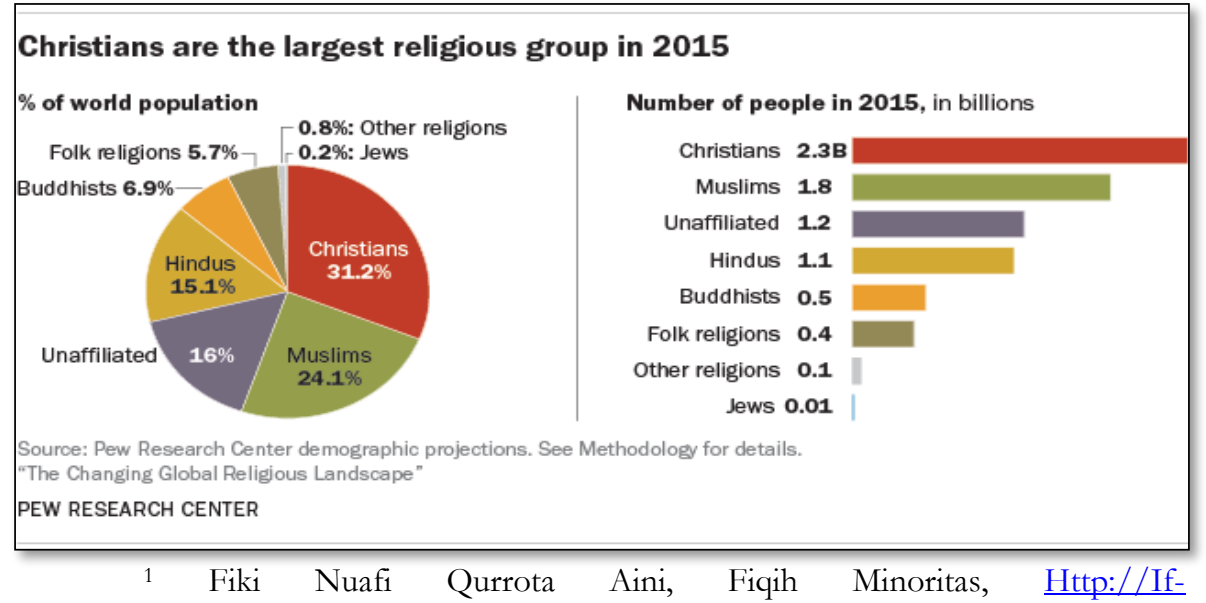

Pasca.Walisongo.Ac.Id/, Mengutip Mubasirun, "Persoalan Dilematis Muslim Minoritas Dan Solusinya” Episteme, Vol.10, No.1, Juni 2015, hlm.102-103.

2 Https://Www.Pewresearch.Org/Fact-Tank/2017/04/05/ChristiansRemain-Worlds-Largest-Religious-Group-But-They-Are-Declining-In-Europe/ 
terbesar di dunia pada tahun 2015, membentuk hampir sepertiga (31\%) dari 7,3 miliar penduduk Bumi. Akan tetapi laporan itu juga menunjukkan bahwa jumlah orang Kristen di benua Eropa, sedang mengalami penurunan yang jelas dan signifikan.

Umat Kristen memiliki
kelahiran dan kematian
terbanyak dari kelompok agama
mana pun dalam beberapa
tahun terakhir. Antara 2010 dan 2015, diperkirakan 223 juta bayi lahir dari ibu Kristen dan sekitar 107 juta orang Kristen meninggal dengan peningkatan alami 116 juta. Tetapi di antara orang-orang Kristen di Eropa Jumlah kematian melebihi jumlah kelahiran sebanyak hampir 6 juta selama periode yang singkat ini. Di Jerman saja, diperkirakan ada 1,4 juta lebih kematian orang Kristen daripada kelahiran dari tahun 2010 hingga 2015.

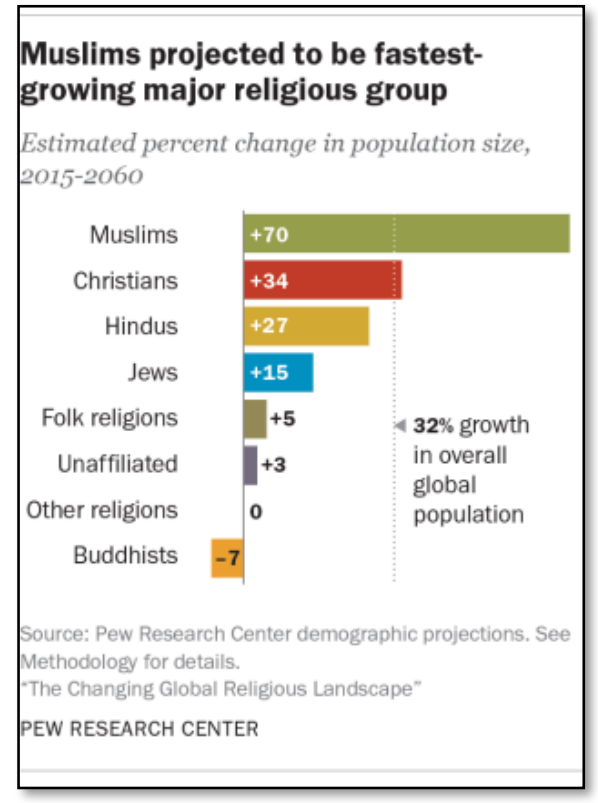

${ }^{3}$ Ibid.,

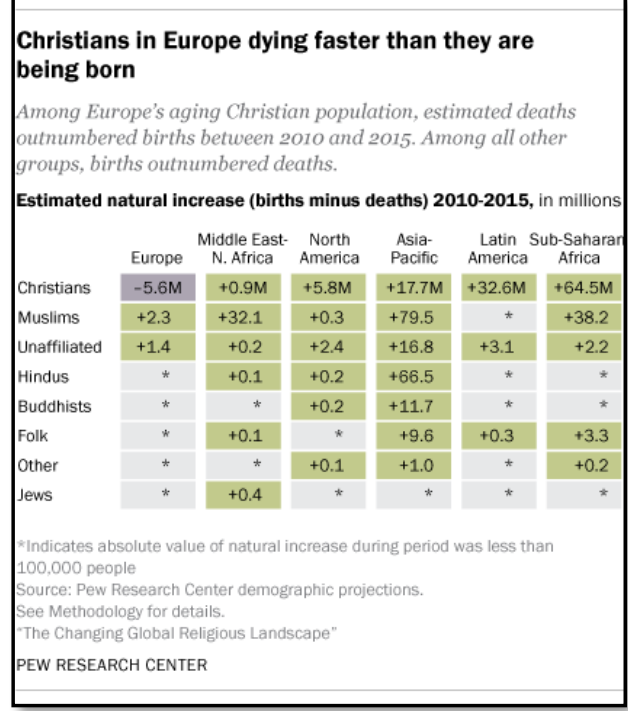

Penurunan alami populasi Kristen di Eropa ini unik dibandingkan dengan orangorang Kristen di bagian lain dunia dan kelompok agama lainnya. Faktanya, Muslim dan mereka yang tidak terafiliasi di Eropa mengalami peningkatan alami dalam populasi mereka. Laporan baru memperkirakan bahwa ada lebih dari 2 juta dan 1 juta kelahiran lebih banyak daripada kematian, masingmasing, antara tahun 2010 dan $2015^{3}$

Secara global, Muslim membentuk kelompok agama terbesar kedua, dengan 1,8 miliar 
orang, atau $24 \%$ dari populasi dunia, diikuti oleh agama "nones" (16\%), Hindu (15\%) dan Buddha (7\%). Penganut agama rakyat, Yahudi dan penganut agama lain merupakan bagian yang lebih kecil dari orangorang dunia. Sementara itu umat Muslim mengalami peningkatan alami terbesar di antara semua kelompok agama, termasuk Kristen. Kelahiran Muslim antara tahun 2010 dan 2015 melebihi jumlah kematian sebanyak 152 juta (213 juta kelahiran vs. 61 juta kematian).. ${ }^{4}$

Penelitian lainnya menyebutkan bahwa Populasi Muslim di dunia diramalkan akan terus bertambah sampai 30\% pada tahun 2030 mendatang. Tingkat pertumbuhan penduduk Muslim diperkirakan mencapai dua kali lipat dibandingkan non-Muslim, di mana rata-rata pertumbuhan Muslim pertahun berkisar 1,5\% sementara non-Muslim hanya berkisar $0,7 \%$ pertahun. Perkiraan pertumbuhan penduduk Muslim ini didasarkan pada data time series, di mana pada tahun 1990 jumlah penduduk Muslim mencapai 1,1 miliyar, tahun 2000 mencapai 1,3 miliyar dengan nilai pertumbuhan $19,9 \%$, tahun 2010 mencapai 1,6 miliyar dengan nilai pertumbuhan $21,6 \%$, tahun 2020 diprediksi mencapai 1,9 miliyar dengan nilai pertumbuhan $23,4 \%$, dan tahun 2030 diproyeksikan mencapai 2,2 miliyar dengan nilai pertumbuhan $24,9 \%$. Dengan demikian, Islam akan menjadi agama yang memiliki perkembangan pemeluk terbanyak di dunia. Artinya, kaum Muslim akan mencapai $26,4 \%$ dari total populasi penduduk bumi yang diproyeksikan mencapai 8,3 miliyar pada tahun $2030 .^{5}$

Data ini tentu menjadi sebuah tantangan tersendiri bagi kaum muslimin. Peneterasi Islam di negara-negara Eropa telah membuahkan hasil yang signifikan. Meskipun umat Islam saat ini tentu saja masih minoritas, namun peran dan pengaruhnya mulai dapat dirasakan. Munculnya syi'ar serta kegiatan Islam, LSM dan organisasi-organisasi Islam, masuknya tokoh-tokoh muslim di parlemen, di pemerintahan, pendidikan, perekonomian, dan lain sebagainya adalah satu hal yang perlu dirawat dan dijaga. Hubungan yang harmonis antara masyarakat dan Negara menjadi salah satu kunci kesuksesan eksistensi muslim minoritas. Untuk itulah makalah ini akan membahas tentang bagaimana fiqih interaksi yang harus dilakukan oleh seorang muslim kepada Negara

${ }^{4}$ Ibid., Lihat Pula Analisa Yang Disebutkan Oleh Laporan Republika. Https://Republika.Co.Id/Berita/Qh7npm320/Jumlah-Muslim-Eropaamerika-SerikatNaik-Ini Momentumnya

${ }^{5}$ Dedi Sahputra Napitupulu Dan Syawal Fahmi, Pendidikan Islam Muslim Minoritas Jurnal Pendidikan Islam, Iain Curup, Vol. 5, No. 01, 2020, Hal. 39. Mengutip 2bahrul Hayat, "Kontribusi Islam Terbadap Masa Depan Peradaban Islam Di Asia Tenggara”, Dalam Jurnal Miqot, Vol. Xxxiv, No. 1, Januari-Juni (2012), Hlm. 193. 
manakala mereka tinggal di negeri yang mayoritasnya adalah non muslim.

\section{Fiqih Aqalliyah; Sebuah tinjauan}

Salah satu solusi yang masih menjadi perbincangan hangat di tengah-tengah akademisi dan peneliti muslim adalah penerapan fiqih baru yang disebut dengan fiqih aqalliyah. Berangkat dari kenyataan di atas, maka keberadaan muslim minoritas seringkali mendapatkan problem dalam menjalankan agama. Baik promblematika yang berkaitan dengan ibadah, mu'amalah, bahkan sebahagiannya masuk dalam ranah aqidah. Untuk itulah fiqih aqalliyah lahir sebagai sebuah metodologi fiqih yang mencoba untuk menjembatani masalah masalah tersebut, agar kehidupan minoritas muslim di Negara mayoritas non Muslim dapat membawa kemaslahatan baik bagi dirinya maupun orang banyak.

Dr. Ziyad bin Hammad Al 'Amir dalam tulisannya berjudul "fiqhul 'Aqady fi al Aqalliyat al Islamiyyah" menjelaskan istilah al aqalliyat secara bahasa dan isthilah sebagai berikut;

$$
\text { الأقليات في اللغة: جمع أقلية وهي خلاف الأكثرية }
$$

(Secara bahasa al aqalliyyat adalah bentuk jama dari aqalliyah, yang maknanya adalab kebalikan dari aktsariyyah.)

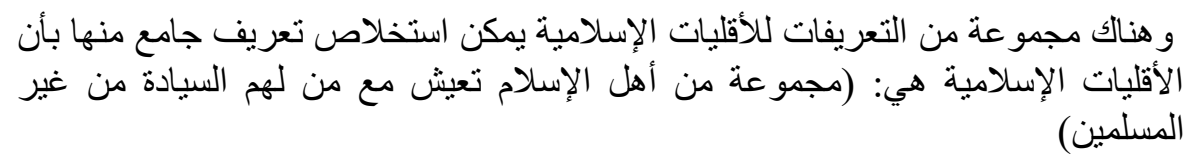

(adapun al aqaalliyyat al islamiyyah secara terminologi dapat disimpulkan dari beberapa definisi yang ada yaitu; kelompok ablul islam (kaum muslimin) yang tinggal ditempat yang dikuasai oleh orang-orang diluar Islam)

Tâhâ Jâbir al-'Alwânî melalui bukunya, Toward a Fiqh for Minorities: Some Basic Reflections, dan Yûsuf al-Qaradawî dalam Fî Fiqh alAqaliyyât al-Muslimah, dianggap sebagai orang yang pertama yang mengenalkan terminologi fiqh Al Aqalliyat ini. Memang, problematika hukum Islam di kalangan minoritas telah banyak terjadi sebelum istilah fiqh ini muncul, dan pendapat-pendapat hukum untuk masyarakat Muslim minoritas pun banyak dan beragam. Namun, kedua tokoh inilah yang menggagas perlunya suatu bentuk fikih yang khusus dan utuh dari sisi materi dan metodologinya. ${ }^{6}$

${ }^{6}$ Kalau Dalam Fikih Pada Umumnya, Produk Hukum Didasarkan Pada Hujiziah Al-Nass (Otoritas Nas), Maka Produk Hukum Dalam Fiqh Al-Aqaliyyât 
Gagasan keduanya ini kemudian mendapat tanggapan luas sehingga menjadi diskursus publik.Tulisan-tulisan dalam bentuk buku dan artikel pun tentang fiqh al-aqaliyyât mulai banyak diterbitkan, seperti tulisan Bin Bayyah, M. Khalid Mas'ud, Shammai Fishman, Mathias Rohe, dan Wahbah al-Zuhaylî. Ada menolak, Ada yang mendukung, menguatkan, memperbaiki sisi metodologi, namun adapula yang menggunakannya untuk menguatkan pandangan-pandangan liberalisasi agama ${ }^{8}$.

Untuk itu, pendapat penulis tentang bagaimana interaksi minoritas muslim kepada negaranya pada tulisan ini akan mencoba merujuk kepada pandangan ulama salaf dan kemudian mengkombinasikannya dengan pandangan ulama-ulama fiqih kontemporer dari berbagai latar belakang akademisi yang terkenal dengan keilmuannya di bidang fiqih. Hal itu untuk menjaga pandangan yang menyimpang pada sikap ekstrim kanan maupun ekstirm kiri pada fiqih yang masih diperdebatkan ini.

Didasarkan Pada Hujjizah Al-Maqâsid (Kekuatan Nilai-Nilai Tujuan Syarak), Yaitu Untuk Mendapatkan Kemaslahatan Dan Menghilangkan Kemudaratan. Untuk Itulah Pandangan

7 Nurhayati, Fikib Minoritas: Suatu Kajian Teoretis, Jurnal Ahkam, Uin Jakarta, Vol. Xiii, No. 2, Juli 2013, hal. 196. Penulis Mengutip Dari; Ahmad Imam Mawardi, Fiqh Minoritas: Figh Al-Aqalliyyat Dan Evolusi Maqashid Al-Syariah Dari Konsep Ke Pendekatan, (Yogyakarta: Lkis, 2010), hal. 116.

8 Dalam Tulisannya Di Jurnal Imam Ahmad Mawardi Menuduh Bahwa Mereka Yang Tidak Sependapat Dengan Fiqih Aqalliyah Sebagai Pihak Yang Tidak Moderat Dan Cenderung Fanatik Buta. Mawardi Kemudian Mencontohkan Adanya Kelompok Yang Tidak Dapat Menerima Perbedaan Antara Sunni Dan Syi'ah. Padahal Menurutnya Perbedaan Itu Hanya Pada Tingkatan Furu'iyyah. Yang Menjadi Sorotan, Gagasan-Gagasan Mendukung Fiqih Aqalliyah Didukung Oleh Para Sarjana Kontemporer Yang Memiliki Cara Pandang Liberal Seperti; Nashir Hamid Abu Zaid, Fazlur Rahman, Ahmad An Na'im, Dan Lain-Lain. Lihat, ${ }^{8}$ Imam Ahmad Mawardi, Fiqih Mayoritas Versus Fiqib Minoritas, Jurnal Justicia Islamica, Vo. 9. No. 2, Desember 2012, hal. 105-118

9 Melihat objek kajian fiqihnya, sesungguhnya istilah yang juga mencakup pembahasan fiqih minoritas bisa dikatagorikan dalam istilah fiqih lain yang juga mu'tabar seperti; fiqib nawazil, fiqib mu'ashirah, fatawa mu'ashirah, nazhariyyat wa zhawabir. Karena fiqih semacam ini membahas hal-hal kontemporer yang belum ditemukan nash dan fatwanya pada masa lalu, dan diperlukannya dimasa kini. Lihat, Muhammad yusri bin ibrahim, Fiqhu Nawazil, Lil Aqalliyat Al Muslimab; Ta'shilan Wa Tathbiqan, Qathar: Wizarah Awqaf Wa Su'un Al Islamiyyah, 2013, Jilid 1, hal. 32 


\section{HASIL DAN DISKUSI}

\section{Negeri Kafir dan Hukum Bermukim}

Sebelum kita membahas bagaimana kewajiban yang harus dilakukan bagi seorang muslim terhadap negaranya di Negara mayoritas non Islam, maka kita perlu mendudukkan terlebih dahulu persoalan bagaimana sesungguhnya padangan fiqih Islam klasik tentang hukum tinggal di Negara non Islam. Legitimasi fiqih Islam klasik yang sudah mapan ini penting karena ia mendasari aplikasi selanjutnya bagi aktifitas seorang muslim di negera tersebut.

Para ulama Islam baik salaf maupun khalaf telah membahas permasalahan ini dengan terlebih dahulu mendefinisikan jenis negara yang didiami tersebut. Dalam terminologi fiqih maka kita akan menemukan term darul Islam dan darul kufur. Atau musthalahat lainnya seperti darul murtakib, darul da'wah, dan lain-lain. Merujuk kepada pendapat para ulama' maka Istilah yang paling tepat untuk mendefinisikan Negara mayoritas non muslim yang saat ini ada di Negara-negara eropa adalah darul kufr.

Secara istilah Negara kufr sebagaimana disebutkan oleh Imam Abu Ya'la adalah: ${ }^{10}$

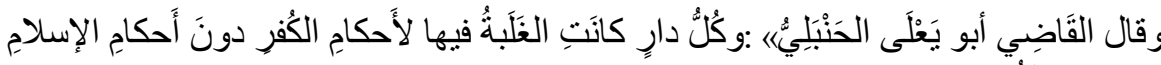

$$
\begin{aligned}
& \text { فهي دارُ الكُفر أرِ }
\end{aligned}
$$

(setiap Negara yang berlaku padanya bukum-bukum kekufuran selain dari bukum Islam, maka ia adalah negar kafir).

Juga sebagaimana pendapat yang dikeluarkan oleh Lembaga Riset dan Fatwa Kerajaan Saudi Arabia bahwa;

"Setiap Negara dimana para hakim dan penguasanya tidak mengatur negaranya dengan hukum Islam, dan tida pula penduduknya memiliki kekuatan untuk menjalankan syi'ar-syi'ar Islam, maka itu adalah negar kafir... . Dan termasuk pula negeri yang dinisbatkan penduduknya kepada Islam akan tetapi penguasanya menjalan hukum selain hukum Islam, dan kaum muslimin di dalamnya tidak dapat menjalankan syi'ar Islam maka negeri tersebut juga disebut Negara kafir. ${ }^{11}$

10 'Ali Muhammad Wanis, Hukmu Iqmah Fi Bilad Al Kuffar, Saudi Arabia: Markaz Tsabit Lil Buhuts Wa Dirasat: 2016, hal. 34-35

11 Ali Muhammad Wanis, Hukmu Iqmah Fi Bilad Al Kuffar, Hal. 37-38, Fatawa Al Lajnah Ad Da'imah, Jilid 12, 48-53, Fatwa No. 2635 
Adapun Negara Islam adalah kebalikannya yaitu sebagiamana dikatakan oleh :

$$
\text { قال ابن مفلح المقدي :كل دار غلب عليها أحكام المسلمين فدار الإسلام }
$$

(Ibn Muflih Al Maqdisi berkata: Setiap Negara yang berlaku secara mayoritas padanya bukum-bukum kaum muslimin, maka disebut Negara Islam). ${ }^{12}$

Hal ini diperkuat pula oleh pendapat pakar ilmu da'wah kontemporer Prof. Dr. Abdul Karim Zaidan; ${ }^{13}$

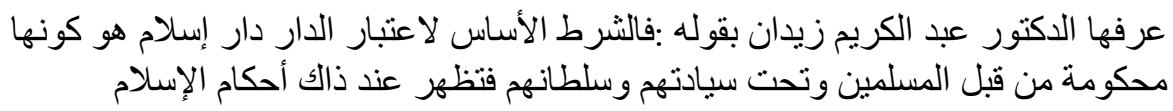

(Dr. Abdul Karim Zaidan mendefinisikan Negara Islam: Syarat dasar untuk. menganggap Negara itu sebagai Negara Islam adalab bahwa Negara itu dikuasai oleh umat Islam dan berada di bawah kedaulatan dan otoritasnya, sehingga pada saat itu muncul bukum-bukum Islam.)

Berkenaan dengan definisi di atas, maka negeri-negeri yang dikuasai oleh orang-orang kafir dan tidak menjalankan hukum-hukum Islam di mana kaum muslimin tinggal di dalamnya saat ini dikenal dengan istilah darul kufr ${ }^{14}$.

Oleh karena itu, para ulama salaf terdahulu telah memberikan penjelasan panjang lebar mengenai hukum tinggal di Negara jenis ini. Apakah mereka boleh tinggal menetap di negeri tersebut ataukah harus melakukan hijrah ke negeri Islam yang memungkinkan untuk mereka tinggal di dalamnya. Mengenai hal ini, Prof. Dr. Mulfi bin Hasan As Syahri menjelaskan dengan panjang lebar dalam kitabnya Haqiqatu Darain; Darul Islam wa Darul Kufr pendapat dua kelompok besar antara yang membolehkan dengan syarat dan melarang secar mutlak.

Adapun pendapat yang paling dipilih oleh beliau sendiri adalah pendapat yang membolehkan seseoang muslim tinggal di negeri kufur

${ }^{12}$ Tharif Khadr Sulaiman, Al Qismah Al Tsana'iyyah Li Dar Baina Al Mujiz. Wa Al Mani', Jurnal Tarbiyah Al Asasiyyah, Vol. 10, No. 1, Hlm. 167. Lihat, Ibn Muflih Al Maqdisi, Al Adab As Syar'iyyah, Tahqiqh: Syu'aib Al Arnauth, Beirut: Mu'assasah Al Rislah, 1999, Jilid 1, Hal. 211

13 Abdul Karim Zaidan, Abkam Adrimmiyyin Wa Al Musta'minin Fi Dar Al Islam, Beirut: Mu'assasah Ar Risalah, 1982 Hal. 18

14 Prof. Dr. Mulfi Bin Hasan As Syahri Menjelaskan Dalam Kitabnya Haqiqatu Darain; Darul Islam Wa Darul Kufr Bahwa darul kuruf masih terbagi menjadi tiga; yaitu kufur harbi (negara yang memerangi islam), kufur mu'ahad (negara yang terlibat perjanjian), dan kufuar al hiyad (negara yang tidak terlibat peperangan dua belah pihak dan memilih untuk berdamai) lihat, Mulfi Bin Hasan As Syahri, Haqiqatu Darain; Darul Islam Wa Darul Kufr, Abha Saudi Arabia: Dar Al Murabihtin, 2010, hal. 115 
namun dengan ketentuan-ketentuan yang juga harus ditegakkan seperti; tetap terjaganya agama, harta, kehormatan seorang muslim, dan kemampuan untuk menjaga syari'at. ${ }^{15}$ Oleh karena itu, beliau menyimpulkan hukum bermukim di Negara kafir ini dapat berubah sesuai dengan kondisi Negara dan orang yang mukim di dalamnya menjadi beberapa derajat; Wujub, istibbab, al karahiyyah, al ibahah, dan al burmah.

\section{Interaksi Minoritas Muslim terhadap Negara}

a. Muslim minoritas berkewajiban untuk menda'wahkan Islam kepada Masyarakat dan Negara

Dr. Ali Muhammad Wanis, Hukmu Iqmah fi Bilad al Kuffar menjelaskan bahwa Kaum muslimin yang tinggal di Negara non muslim, maka dirinya memiliki kewajiban memberikan contoh kehidupan yang berlandaskan pada asas Islam yang agung. Maka ia wajib untuk berda'wah dengan mu'amalah yang baik. ${ }^{16} \mathrm{Hal}$ itu sebagaimana tersebarnya Islam di seperempat negera-negar Asia dan Afrika yang dilakukan melalui alat perdagangan sambil menunjukkan keluruhan akhlaq. Demikian itu dapat menarik simpati penduduk dan merekapun berbondong bondong masuk ke dalam Islam. Beliau mengatakan;

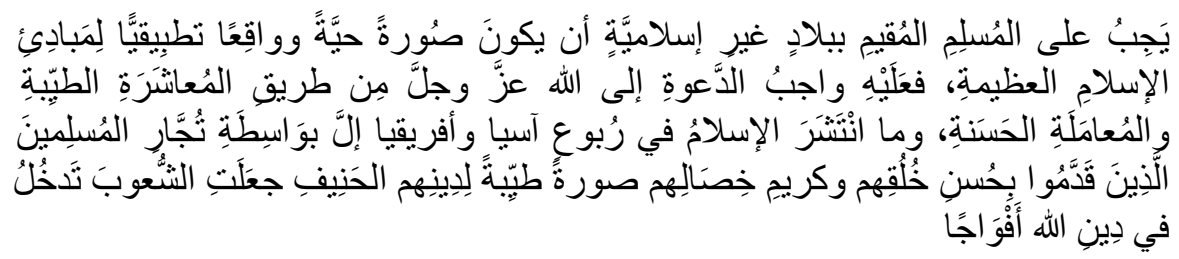

Hal itu pula yang dilakukan oleh para sahabat pada saat hijrah ke Negeri Habasyah. Dimana Ashamah Raja Najasyi tertarik dengan Islam setelah terjadi dialog segitiga antara kaum muslimin yang diwakili oleh sahabat Ja'far bin Abi Thalib, Amru bin al Ash dan Abdullah bin Abi Rabi'ah dari pihak utusan lobi Quraish ${ }^{17}$, dihadapan Raja dan para pendeta Ahlul Kitab. ${ }^{18}$

${ }^{15}$ Ibid. hal. 181

16 'Ali Muhammad Wanis, Hukmu Iqmah Fi Bilad Al Kuffar, Tt; Markaz Tsabat Lil Buhhuts Wa Ad Dirasat, 2016, Hal. 152

17 Riwayat Ibn Katsir Menyebutkan Amru Bin Al Ash Dan 'Umarah Ibn Al Walid. Lihar, Abi Al Fida’ Ibn Katsir, As Sirah An Nabawiyah Min Al Bidayah Wa An Nihayah, Beirut: Dar Al Ma'rifah, 1976, Jilid 2, Hal. 5

18 Muhammad Bin Muhammad As Syuwailim, As Sirah An Nabawiyah Fi Dhau'i Al Qur'an Wa As Sunnah, Damaskus: Dar Al Qalam, 1427, Jilid I, Hal. 375 
Da'wah yang dilakukan di Negara non muslim seperti ini harus dikembalikan kepada manhaj da'wah Rasulullah pada periode Makkah. Salah satu pokok manhaj yang perlu dijaga adalah; manbaj tadarruj fi ad da'wah.

Pakar Ilmu da'wah Prof. Dr. Abul Fatah Al Bayanuni dalam kitabnya Al Madkbal ila 'ilmi ad da'wah menyebutkan bahwa secara umum ada 3 pokok karekateristik dari manhaj da'wah para Nabi yaitu; khasyisah al indibath (karakteristik untuk da'wah selalu teguh memegang syari'at), khasyisyah at tadarruj (karakteristik bertahap dalam da'wah), dan khasyisyah al istimrar (karakteristik selalu berkelanjutan dan tidak terputus sampai hari kiamat). ${ }^{19}$

Asas tadarruj pada masa Nabi dapat ditinjau dari beberapa aspek berikut; Pertama, Ditinjau dari aspek waktu gradualitas hukum Islam pada masa Nabi berlangsung kurang lebih 22 tahun 2 bulan. Dalam kurun waktu tersebut syari'at islam diberlakukan secara bertahap. Kedua, aspek jenis hukum. Ditinjau dari aspek jenis hukum, maka gradualitas pada masa Nabi ditujukan untuk kemudahan pelaksanaan hukum itu sendiri oleh umat Islam. Ketiga, aspek penjelasan hukum. Syari'at Islam diturunkan mulia dari aspek-aspek yang bersifat universal dan fundamental hingga aspek-aspek yang bersifat rinci dan cabang $($ furu $) .{ }^{20}$

Diantara karakteristik syari'at Islam adalah, ia datang secara bertahap. Dalil pensyari'atan tadarruj ini dapat dirujuk pada al Qur'an surah Al Isra': 106 dan Al Furqan: 32.

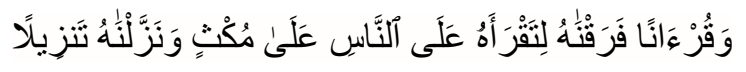

Dan Al Quran itu telah Kami turunkan dengan berangsur-angsur agar kamu membacakannya perlahan-lahan kepada manusia dan Kami menurunkannya bagian demi bagian. (QS. Al Isra': 106)

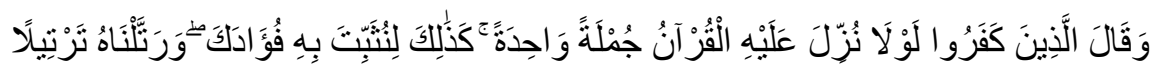

Berkatalah orang-orang yang kafir: "Mengapa Al Quran itu tidak diturunkan kepadanya sekali turun saja?"; demikianlah supaya Kami perkuat batimu dengannya dan Kami membacanya secara tartil (teratur dan benar). (QS. AlFurqan : 32)

Selain ayat-ayat di atas, landasan tadarruj juga dapat ditemukan dalam banyak riwayat diantaranya riwayat tentang turunnya surah $\mathrm{Al}$ 'alaq pada

19 Muhammad Abu Al Fatah Al Bayanuni, Al Madkhal Ila Ilmi Ad Da'wah, Damaskus: Mu'assasah Ar Risalah, 2014, Hal. 238-235

${ }^{20}$ Jeje Zaenuddin, Metode Strategi Penerapan Syari'at Islam Di Indonesia, Jakarta: Penerbit Miumi, \& Pembela Islam, 2015, Hal. 75 
saat kenabian tidak dalam satu surah yang lengkap melainkan secara bertahap. $^{21}$

Da'wah ini dilakukan kepada rakyat sebagai penduduk dan bagian dari Negara dengan beragam status sosial dan perannnya, dan juga da'wah kepada pemegang urusan Negara di semua bidangnya. Mereka yang memiliki kemampuan untuk melakukan hal ini bisa masuk kedalam hukum sunnah maupun wajib. Negeri-negeri di Asia seperti Indonesia, Malaysia, Brunai Darussalam, Singapura (dulu), dan selainnya adalah hasil dari metode da'wah kelompok minoritas kepada mayoritas penduduk yang beragama Hindu dan Budha, sampai berhasil mewujudkan institusi kesultanan Islam yang berpengaruh di sejumlah Negara di atas.

\section{Menjaga pelaksanaan syari'at agama yang pokok pada individu dalam hidup bernegara}

Seseorang yang tinggal di negeri kufur yang aman, maka ia harus menjaga pribadi masing masing dengan cara saling menguatkan antar sesama muslim dengan membentuk ikatan organisasi muslim yang kuat, dimana mereka dapat melakukan kegiatan-kegaitan seperti pendidikan, pengajaran, kegiatan sosial, dan lain-lain yang memperkuat penjagaam agama dari beragam kerusakan yang ada di negara kufur tersebut. ${ }^{22}$ Sejauh ini kita mendapati bahwa mayoritas negeri-negeri non muslim ini, meski sudah memberikan izin tinggal secara aman kepada minoritas, namun pengaruh kehidupan dan pergaulan di dalamnya sangatlah besar.

Kebebasan dalam berpakaian, makan dan minum, bergaul, secara jelas akan dapat mengikis keimanan jika mereka tidak memiliki faktor-faktor yang mampu menjaga agama. Oleh karena itu, Ibunda A'isyah ketika ditanya tentang hijrah, Beliau berpendapat bahwa hijrah hanya terjadi sebelum fathul Makkah, maka setelah Fathul Makkah tidak lagi terjadi hijrah. Menurut Al Imam Ibn Hajar Al Atsqalani maksud ibunda 'Asiyah pada riwayat tersebut menjelaskan bahwa hijrah itu terjadi karena ada sebab yang melatarbelakanginya (illat). Namun ketika sebab itu sudah tidak ada. Maka hal itu tidak terjadi. Oleh karena itu $\mathrm{Al}$ Imam Ibn Hajar menjelaskan dalam syarahnya;

${ }^{21}$ Ahmad Farid Shaliih Abu Hazim, Manhaj Al Qur'an Al Karim Fi Tadarruj Wa Atsarubu Fi Taghyir, Universitas Utsman Qabus, Oman, Jurnal As Syari'ah Wa Dirasah Islamiyyah, September 2017, Hal. 45

22 Surahman Hidayat, At Ta'ayis Baina Al Muslimin Wa Ghairibim Dakbila Daulatin Wabidah, Mesir: Dar As Salam, 2001, Hal. 429 


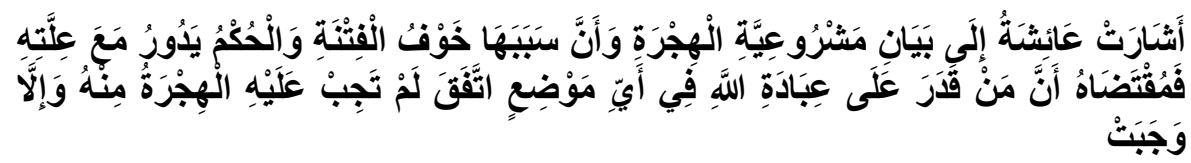

(Berkata Imam Ibnu Hajar: merupakan isyarat dari Ummul Mukminin 'Aisyah bahwa disyariatkannya bijrah itu sebabnya adalah takut terjadinya fitnah. Adapun bukum itu berlaku sesuai dengan illatnya. Maka barangsiapa yang sanggup untuk beribadah kepada Allah disuatu tempat, maka disepakati tidak wajib bagiya hijrah meskipun telah diwajibkan. $)^{23}$

Fitnah yang dimaksud disini adalah gangguan atau sesuatu yang dapat merusak agama seseorang. Yaitu berupa ujian, hambatan, tekanan yang mungkin saja terjadi di negeri kufur terhadap masyarakat yang tidak mengikuti ajara agama yang dipegang oleh penguasa. Jika fitnah tersebut tidak terjadi, maka sikap seseorang ketika tinggal di Negara kufur dia dapat tinggal disana dan menjalankan kewajiban syari’at yang dipikulkan kepadanya sesuai kemampuannya. Atau dia dapat pula memilih untuk hijrah dan mencari negeri yang lebih aman terhadap pelaksanaan syari'at agamanya. ${ }^{24}$

Syari'at-syari'at yang pokok itu seperti rukun Islam yang lima yaitu; syahadat, shalat fardhu, menunaikan puasa, zakat, Ibadah Haji. Jika hubungan terhadap Negara pada penerapan syari'at ini mendapatkan gangguan, maka jika ia memiliki kemampuan, seseorang dapat melakukan hijrah ke negeri-negeri lain yang memungkinkan terlaksananya syari'at tersebut. Bahkan kemaslahatan seseorang yang memiliki kemampuan untuk tetap tinggal di negeri kufur, ia tidak disyari'atkan untuk Hijarh.

Dr. Ali Muhammad Wanis menjelaskan, itulah sebabnya mengapa Nabi tidak memerintahkan kepada Raja Habasyah untuk hijrah dari negerinya menuju Madinah. Hal itu karena ia memiliki kemampuan untuk menghadapi situasi dan gejolak yang ada dinegerinya ketika menunjukkan keislamannya. Demikian pula hal itu ditunjukkan oleh Nabi kepada sebahagian sahabat untuk tidak ikut hijrah padahal ia

${ }^{23}$ Ahmad Bin Ali Bin Hajar Al Atsqalani, Fatbul Bari Syarah Sabih Al Bukhari, Beirut: Darul Ma'rifah, 1379, Jilid 7, Hal. 229

${ }^{24}$ Syaikh Yusuf Al Qardhawi Ketika Ditanya Seseorang Tentang Syarat Tinggal Di Negeri Barat Yang Notabene Adalah Negeri Kufur Makara Beliau Menjawab Hendaknya Seseorang Menjaga Hal Berikut Ini;

إخو انه المسلى دينه، وينمي حياته الروحية و الثقافية و الفكرية، ويحافظ على أسرته؛ زوجنه و أو لاده، ويتعاون مع

(Hendaknya Ia Menjaga Agamanya, Dan Menumbuhkan Ruhiyahnya, Wawasannya, Pemikirannya, Menjaga Keluarga, Istri Dan Anak-Anaknya, Serta Bertolong Menolong Sesame Kaum Muslimin Di Negeri Tersebut). Lihat, Https://Www.AlQaradawi.Net/Node/4160 
mampu melakukan hijrah seperti paman beliau Al Abbas bin Abdul Muthalib dan selainnya. ${ }^{25}$

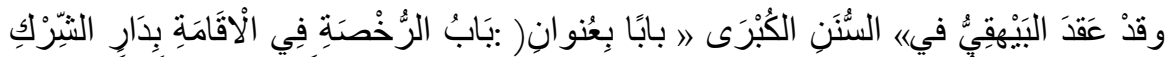

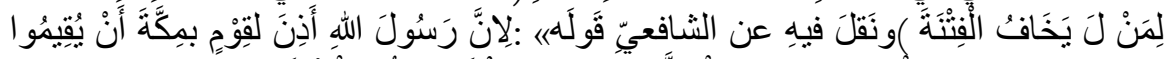

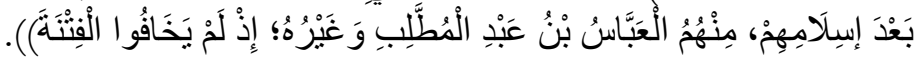

(Imam Al Baihaqi di dalam kitabnya As Sunan Al Kubra bab berjudul "Bab Rukhsah tinggal di negeri syirik bagi yang tidak takut terjadi fitnah) dan dinukil didalamnya dari Imam As Syafi'i: "Karena sesuggubnya Rasulullab telah mengizinkan sekelompok sababat untuk tetap berdiam di Makkah setelah keislaman mereka, diantaranya Al Abbas bin Abdul Muthalib dan selainnya, ketika tidak ditakutkan terjadi fitnah (dalam agama).)

\section{Menjaga aturan syari'ah yang telah ijma' tentang kehalalan dan keharamannya, meskipun Negara melegalkannya.}

Dalam Islam, ketaatan seseorang muslim di negeri Islam, dibatasi dengan batasan syar'i. Yaitu senantiasa menaati aturan dan perundang-undangan yang tidak bertentangan dengan syari'at Islam. Dari Ali bin Abi Thalib radhiallabu'anhu, Rasulullah Shallallabu'alaibi wa sallam bersabda:

$$
\text { لَا طَاعَةَ فِي مَعْصِيَةٍة إِنَّمَا الطَّاعَةُ فِي الْمَعْرُوفِ }
$$

"Tidak ada ketaatan di dalam maksiat, taat itu hanya dalam perkara yang ma'ruf' (HR Bukhari, no. 7257; Muslim, no. 1840). ${ }^{26}$

Hal ini juga berlaku umum kepada siapa saja yang mengurusi urusan umum. Baik itu pemimpin negara, pemimpin organisasi, bahkan hingga pemimpin rumah tangga. Maknanya, jika di suatu negeri telah ditetapkan perintah dan undang-undang yang jelas bertentangan dalam ajaran Islam, maka ia diminta untuk sebisa mungkin untuk menjauhinya. Apalagi jika undang-undang tersebut tidak bersifat ijbari

25 'Ali Muhammad Wanis, Hukmu Iqmah Fi Bilad Al Kuffar, Hal. 105. Beliau Menukil Sumber Tersebut Dari Sejumlah Kitab Diantaranya; As Sunan Al Baihqi Al Kubra, Jilid 9, Hal. 25, Majma’ Az Zawa'id, Jilid 5, Hal 252, Al Mughni Li Ibn Al Qudamah, Jilid 9, Hal. 295

26 Syaikh As Sa'di Menjelaskan Bahwa Sesuatu Yang Ma'ruf Adalah Segala Bentuk Kebaikan Dan Ketaatan Dan Apa Apa Yang Dianggap Baik Oleh Syari'at Dan Akal Membernarkannya. Jadi Patokan Utamanya Adalah Syari'at, Baru Kemudian Akal Yang Befirikan Lurus Yang Ikut Membernarkannya.

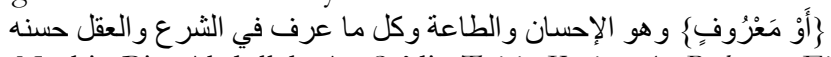

Lihat, Abdurrahman Bin Nashir Bin Abdullah As Sa'di, Taisir Karim Ar Rahman Fi Tafsir Kalam Al Mannan, Riyadh: Muassasaah Ar Rislah, 2000, hal. 202 
(paksaan) atau ia adalah undang-undnag yang bersifat khiyari (pilihan dan anjuran).

Dr. Ali Muhammad Wanis kembali menjelaskan bahwa;

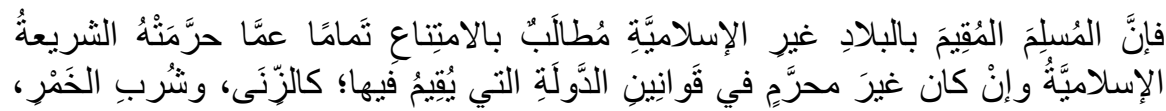

و غيرِ ذاللك

Maka seorang muslim yang tinggal di negeri selain negeri Islam bendaknya ia sepenubnya menjaga hal-hal yang diharamkan oleh syariat Islam meskipun undang-undang Negara tersebut melegalkannya seperti; zina, minum khamar, dan lainnya)

Penjagaan terhadap halal dan haram ini bersesuaian dengan hadits Nabawi tentang wajibnya seorang muslim menjaga ketaqwaannya dimanapun mereka berada. Dari Abu Dzar Al Ghifari radhiallahu'anhu, ia berkata: 'Rasulullah Shallallahu'alaibi $W$ asallam bersabda,

$$
\text { اتق الله حيثما كنت ، و أتبع السيئة الحسنة تمحها، وخالق الناس بخلق حسن }
$$

Bertaqwalah kepada Allah dimanapun engkau berada, dan hendaknya setelah melakukan kejelekan engkau melakukan kebaikan yang dapat menghapusnya. Serta bergaulah dengan orang lain dengan akblak yang baik"” (HR. Ahmad 21354, Tirmidzi 1987, ia berkata: 'hadits ini hasan shahih')

Abdullah bin Shalih al Muhsin menerangkan kalimat "baitsu ma kunta" pada hadits ini bersifat umum yang bermakna tempat dimana saja $^{27}$. Maka dapat diartikan pula, bahwa menjaga ketaqwaan dari hal-hal yang diperintahkan untuk dijauhi bermakna pula perintah bertaqwa di Negara-negara manapun termasuk di negeri-negeri kufur. Bahkan ketaqwaan di negeri kufur tentu sangat lebih dibutuhkan.

\section{Kewajiban untuk terlibat dalam proses membangun Negara dan menyelesaikan persoalan Negara}

Pada bulan Mei 2017, Sadiq Khan terpilih menjadi Wali Kota Muslim Pertama di kota London. ${ }^{28}$ Pada 2019 lalu, perempuan berhijab atas nama Ismail juga berhasil terpilih menjadi walikota muslimah pertama di Inggris. Pada 1980-an Rakhia melakukan imigrasi dari Somalia ke Inggris. Setelah 40 tahun lamanya, kini Rakhia sukses menjadi walikota wanita muslim pertama di Inggris. Masih di Kawasan Eropa, muncul

\footnotetext{
27 Abdullah Bin Shalih Al Muhsin, Abadits Arba'in An Nawawiyah Ma'a Ma Zaada 'Alaiba Ibn Rajab, Madinah: Al Jami'ah Al Islamiyah, 1984, hal. 35

${ }^{28} \mathrm{Https}$ // Padangkita.Com/Ini-Sosok-Perempuan-Yang-Jadi-WalikotaMuslim-Pertama-Di-Inggris/
} 
nama muslim lainnya yang menjabat sebagai wali kota muslim di Rotterdam. Pria bernama Ahmed Aboutaleb ini merupakan seorang muslim kelahiran Maroko. Pada tahun 1976, ia bersama keluarga pindah ke Belanda. Ahmed tumbuh dan berkembang menjadi seorang muslim minoritas di Belanda. Meski begitu, ia mampu berbaur hingga meraih gelar sarjana teknik. Usai lulus, Ahmed bekerja sebagai reporter sebuah media. Selanjutnya, ia bekerja di humas Kementerian Kesehatan Belanda. Tahun 2008, Ahmed mendapat kesempatan menjadi wali kota muslim pertama di Belanda. Nggak hanya itu, ia juga menjadi Wali kota Rotterdam pertama dari imigran.

Naheed Nenshi merupakan wali kota Calgary, Alberta, Kanada. Naheed merupakan wali kota muslim pertama di Amerika Utara. Naheed telah memenangkan pemilihan sebanyak dua kali, yaitu pada tahun 2010 dan 2013. Naheed sendiri terlahir dari keluarga imigran muslim Tanzania yang pindah ke Kanada. Ia tumbuh dan berkembang dengan lingkungan yang multikultural. Naheed menjadi minoritas di lingkungannya, meski begitu ia mampu berdampingan dengan perbedaan yang ada ${ }^{29}$ Dr. Saud Anwar imigran asal Paksitan juga terpilih sebagai Walikota South Windsor, sebuah kota di negara bagian Connecticut pada tahun 2016. Ini merupakan sejarah dalam pemerintahan di Amerika Serikat, untuk pertama kalinya South Windsor mempunyai Walikota Muslim. ${ }^{30}$

Fakta-fakta di atas (dan masih banyak lagi) adalah ralitas kehidupan sosial dimana seorang muslim minoritas dapat berinteraksi dengan baik kepada masyarakat dan Negara secara sekaligus dan bahkan mendapatkan mandat untuk mengatur urusan kenegaraan. Fakta ini telah menunjukkan sisi integritas seorang muslim baik secara keteladanan (moral) maupun skill (kemampuan). Fakta ini pulalah yang dilukiskan dalam al Qur'an al Karim melalui kisah Nabiyullah Yusuf 'alaibissalam. Nabi Yusuf adalah seorang budak yang diperjualbelikan dan hidup sebagai minoritas tertindas. Namun semunnya berubah setelah beliau selama puluhan $\operatorname{tahun}^{31}$ menunjukkan karakteistik dirinya sebagai seorang muslim yang memiliki kepribadian agung, serta dikuatkan dengan skill perekonomian yang mumpuni. Walhasil, beliaupun mampu

\footnotetext{
29 Https://Www.Brilio.Net/Global/-Kisah-3-Pria-Muslim-Jadi-Wali-KotaDi-Kota-Berpengaruh-Dunia-Barat-170616o.Html

30 Https://Www.Voaindonesia.Com/A/Saud-Anwar-Walikota-Muslim-DiAmerika/3341118.Html

${ }^{31}$ Hasan Al Bashri Dan Ibnu Juraih Berpendapat Bahwa Perpisahan Yusuf Dengan Nabi Ya'qub Berjalan Selama 80 Tahun. Lihat, Abi Al Fida' Isma'il Bin Katsir, Qashash Al Anbiya', Tahqiq: Abu Suhaib Muhammad Bin Samih, Mesir: Dar Ibnul Jauzi, 2005 , Hal. 205
} 
menduduki jabatan sebagai Wazir di negeri Fir'aun Mesir yang notabene adalah negeri kufur ${ }^{32}$. Selain itu pula, Nabiyullah Yusuf ikut serta membantu negeri Mesir dalam konteks penanganan kebutuhan pangan dimasa-masa paceklik dengan kemampuan yang cemerlang.

Meski tidak semua Negara-negara mayoritas non muslim memiliki toleransi dan undang-undang yang melindungi hak-hak minoritas, namun secara umum sistem demokrasi yang dianut hampir di seluruh Negara eropa cukup menguntungkan pihak minoritas. Peluang itu pulalah yang ditangkap oleh lobi-lobi Yahudi di Amerika dan negeranegara Eropa, dimana kelompok minoritas ini bahkan cukup kuat mengendalikan Negara dan perpolitikan tingkat internasional. ${ }^{33}$ Hasil dari lobi-lobi inilah yang ikut mewarnai kebijakan negara-negara Eropa terutama Amerika Serikat ketika berhadapan dengan kaum muslimin. Kasus 11 September 2001 adalah contoh dimana kebijakan AS yang mencuriagi umat Islam minoritas berbuntut persoalan panjang dan terus berkelanjutan hingga hari ini.

Untuk itu, sikap kelompok minoritas muslim juga harus menunjukkan bahwa mereka adalah komunitas yang juga mampu memberikan sumbangsih kepada negaranya. Turut serta dalam pembangunan selama itu adalah hal-hal yang ma'ruf. Seperti; pengentasan kemiskinan, meningkatkan sarana pendidikan dann pengajaran, pembangunan sarana kesehatan, dan lain-lain. Kelompok minoritas tidak boleh melakukan tuntutan-tuntutan secara berlebihan kepada negara, atau memaksasakan kehendaknya. Karena dalam wacana faham multikulturalisme, Will Kymlica mengatakan bahwa pihak minoritas yang memaksakan tuntuntannya cenderung akan dipandang sebagai ancaman bagi negara. ${ }^{34}$

${ }^{32}$ Hamid Ahmad At Tahir, Sabih Qashash Al Qur'an, Terj. Umar Mujtahid, Jakarta: Pustaka Ummul Qura', 2019, Hal. 440

33 Agus Setiawan, Perkembangan Lobi Yabudi Dan Pengarubnya Terbadap Politik Luar Negeri Dan Kongres Amerika Serikat, Jurnal Wacana, Vol. 6 No. 2, Oktober 2004, Hal. 179-190

${ }^{34}$ Umihani, Problematika Mayoritas Dan Minoritas Dalam Interaksi Sosial Antar Umat Beragama, Jurnal Tazkiyya, Iain Syekh Nurjati Cirebon, V. 20, N. 02, 2019, Hal. 249. Lihat: Dody S. Truna, Pendidikan Agama Islam Berwawasan Multikulturalisme: Telaah Kritis Atas Muatan Pendidikan Multikulturalisme Dalam Buku Bahan Ajar Pendidikan Agama Islam Di Perguruan Tinggi Umum Di Indonesia (Jakarta: Kementrian Agama Ri, 2010) Cet. I, Hlm. 359-360 


\section{Kewajiban untuk menjaga hubungan antar sesama penduduk Negara}

Hubungan muslim dan agama lain di negar-negara Eropa mengalami pasang dan surut. John L. Esposito bahkan mencatat bahwa di Negara-negara Barat, terjadi salah pandang yang jelas terhadap Islam. Ekstrimisme dan terorisme telah membuat mereka tidak mengenal Islam yang sebenarnya. Padahal mereka adalah sesama agama yang bersaudara antara Islam dan Kiristen. ${ }^{35}$ Kenyataan ini berujung pada sikap anti Islam dan sikap rasis lainnya yang tentu tidak menguntungkan bagi umat Islam di negeri-negeri Mayoritas non Muslim. Kasus-kasus kebencian kepada Islam dan ajarannya sampai saat ini masih dipertontonkan oleh sebagian komunitas yang dilindungi di Negaranegara Eropa. Kasus Pelecehan karikatur Nabi Muhammad oleh Koran majalah satire Charlie Hebdo yang didukung pula oleh Presiden Prancis Emmanuel Macron. ${ }^{36}$ Juga kasus pelarangan Jilabab di beberapa Negara yang dikuatkan oleh Keputusan Pengadilan Uni Eropa (ECJ) yag melarang penggunaan jilbab di tempat-tempat kerja dan tempat khusus lainnya. ${ }^{37}$ Pelaranggan pendirian tempat ibadah, dan lain-lain.

Dalam Surat al-Anbiya ayat 107 dinyatakan, "Dan tiadalah Kami mengutus kamu, melainkan untuk (menjadi) rahmat bagi semesta alam". Dengan lugas dinyatakan bahwa Islam merupakan agama yang membawa rahmat dan kesejahteraan bagi semua seluruh alam semesta, termasuk hewan, tumbuhan dan jin. ${ }^{38}$ Untuk itu, tidak ada yang perlu ditakutkan dalam Islam karena ia datang membawa kemaslahatan untuk umat baik mu'min maupun kafir. Baik yang beriman kepada Allah maupun yang tidak $^{39}$. Untuk itulah, faktor terbesar dalam mewujudkan hal itu adalah pada aspek interaksi sosial kepada penduduk mayoritas. Minoritas

35 Moh. Zeinudin, Minoritas Muslim Di Barat (Studi Atas Pemikiran Tariq Ramadan), Esensia Vol Xii No. 1 Januari 2011, Universitas Wiraraja Sumenep Madura, Hal. 67. Penulis Merujuk, John L. Esposito, "Benturan Antar Peradaban: Citra Kontemporer Islam Di Barat”, Dalam John L. Esposito, Dkk, Terj. Ahmad Syahidah, (Yogyakarta: Qalam, 2002), Hlm. 131-132.

${ }^{36}$ Https://Www.Bbc.Com/Indonesia/Dunia-54630462

37

Https://Republika.Co.Id/Berita/Dunia-Islam/Islam-

Nusantara/17/03/15/Omu55u328-Turki-Kritik-Larangan-Jilbab-Di-Eropa

38 Andi Rahman, Relasi Antara Muslim Dengan Non Muslim, Jurnal Kordinat Vol. Xv No. 2 Oktober 2016, Hal. 218

39 Imam Ibn Jarir At Thabari Memilih Pendapat Dari Dua Pendapat Yang Ada, Bahwa Ayat Ini (Qs, Al Anbiya: 107) Menjelaskan Tentang Ramhat Yang Diperuntukkan Bukan Hanya Kepada Orang Muslim Dan Mu'min, Namun Juga Bagi Mereka Yang Tidak Beriman., Lihat, Abu Ja'far At Thabari, Jami' Al Bayan Fi Ta'wil Al Qur'an, Tahqiq: Ahmad Syakir, Ryadh: Mu’assasah Ar Risalah, 2000, Jilid 18, Hal. 552 
muslim harus menunjukkan akhlaq Islam yang dominan sehingga dapat mengurangi resistensi dalam kehidupan sosial.

Akhlaq Islam adalah bagian dari rahmat yang mampu menciptakan nuansa perdamaian, keamanan, serta kebahagian dalam hidup. Bahkan dapat menciptakan daya tarik untuk mengenal lebih jauh ajaran Islam, hingga masuk kedalamnya. Itulah mengapa, banyak tokohtokoh non muslim yang justeru memeluk Islam dan bersimpati kepada penduduk muslim setelah melihat kehidupan kaum muslimin yang lebih baik dari apa yang mereka lakukan selama ini.

\section{Tidak melakukan pemberontakan kepada Negara kecuali jika memiliki kemampuan dan setelah melihat besarnya Maslahat yang ditimbulkan.}

Upaya menggulingkan sebuah negara (kudeta) adalah opsi terakhir yang memiliki kemungkinan untuk dilakukan oleh minoritas muslim. Yaitu ketika negara telah melakukan tindakan-tindakan yang menzhalimi rakyat minoritas, terlebih jika negaranya adalah negara kafir. Namun demikian, upaya kudeta ini harus dilakukan secara cermat dan matang. Dengan perhitungan yang benar-benar jelas-jelas akan membawa kepada kemaslahatan pada masyarakat dan ummat yang tidak boleh seorang muslim sembarangan dan serampangan dalam melakukannya.

Dalam Islam, sikap rakyat kepada penguasa ada tiga bentuk. Bentuk pertama, kepada penguasa muslim yang menjalankan syari'at Islam dengan baik dan adil. Kedua, sikap rakyat kepada penguasa kafir yang menjalankan hukum-hukum kekafiran secara terang-terangan. Ketiga, sikap rakyat kepada penguasa muslim di negara muslim, namun berbuat kefasikan dan menyalahi aturan-aturan syari'at. Dr. 'Athiyah Adlan dalam penjelasannya yang dikeluarkan oleh Ma'had Al Mishriyyah li Dirasat As Siyasiyah wa Istratijiyyah (Egyptian Institute for Political and Strategij Studies) yang bertempat di Istambul, menjelaskan bahwa para ulama telah sepakat hukum tentang point pertama dan kedua dalam bentuk ijma'. Sementara itu, mereka berselisih dalam point yang ketiga menjadi tiga kelompok lagi. ${ }^{40}$

Dr. Athiyah melanjutkan, terkait sikap kepada pemimpin yang telah menunjukkan kekufuranya "kufrun bawwahan" termasuk pemimpin yang asalnya adalah muslim, maka para ulama telah sepakat tentang diysari'atkannya keluar dari ketaatan. Sebagiamana hal itu disebutkan

40 Athiyah Adlan, Fi Mas'alah Al Khuruj 'Ala Al Hukkam, Istambul: Ma'had Al Mishriyyah Li Dirasat As Siyasiyah Wa Istratijiyyah, 2017, hal. 2 
oleh Imam An Nawawi, Ibnu Hajar Al Asqalani, Qadhhi Iyadh dan selainnya bahwa pemimpin yang telah tampak jelas-jelas kekufuran padanya maka disyari'atkan untuk mencopotnya atau melakukan perlawanan kepadanya apabila dimungkinkan. ${ }^{41}$

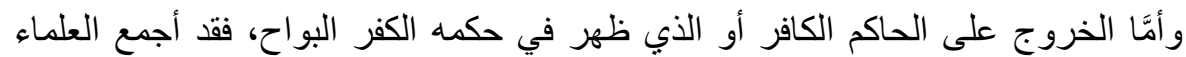

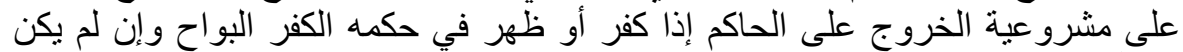

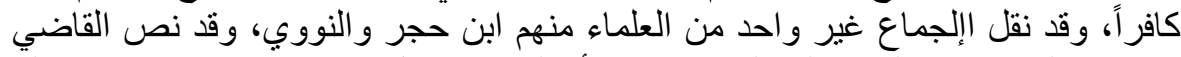

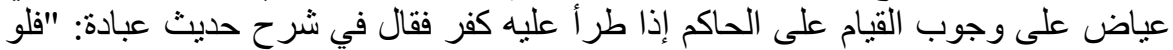

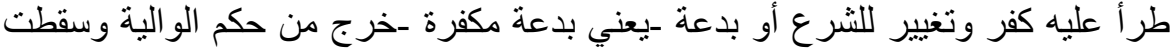

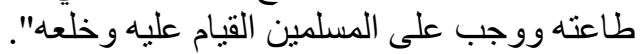

Demikian pula fatwa ulama kontemporer Syaikh Abdullah Ibn Baz rabimabullab ${ }^{42}$ yang juga menyebutkan pandangan bahwa pemimpin yang terlihat jelas kekufurannya dan kita memiliki hujjah atasnya, maka tidak diperbolehkan untuk memeranginya kecuali apabila ummat memiliki kekuatan yang dapat menggantikan pemimpin tersebut ;

الخروج على الحكم محل نظر، فالنبي - صلى الله عليه وسلم ـ قال: إإلا أن ترو ا كفرًا

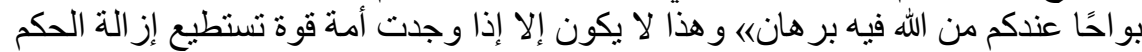

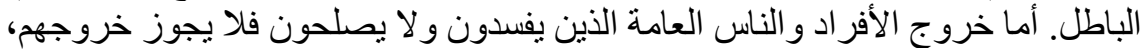
هذا يضرون به الناس و لا ينفعونهم.

Disini Syaikh Ibn Baz menysaratkan adanya kemampuan untuk melakukan hal tersebut. Maksudnya, kemampuan ini benar-benar telah dihitung maslahatnya jauh lebih besar dari madharat yang ditimbulkan. Bukan hanya bermodal pada semangat namun tidak disertai dengan perbekalan pada semua aspeknya secara mendalam.

Bahkan dinukil pula oleh Ibn Hajar Al Atsqalani tentang bolehnya melawan pemimpin muslim yang banyak berbuat kerusakan apabila memiliki kekuatan untuk mencopotnya tanpa menimbulkan fitnah (kerusakan) dan juga kedzaliman. Artinya, jika kepada pemimpin muslim yang telah berbuat kerusakan kita boleh melakukan upaya kudeta dan perlawanan, maka tentu kepada Negara kufur hal itu lebih berhak untuk dilakukan. ${ }^{43}$

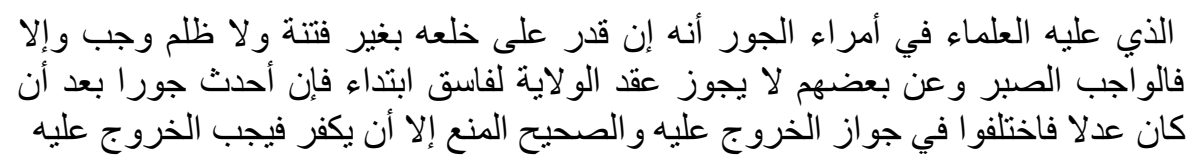

${ }^{41}$ Ibid., Dr. Athiya Menukil Dari Rujukan;

شرح النووي لمسلم 119/21 ،)وقال ابن حجر" :ينعزل بالكفر إجماعاً فيجب على كل مسلم القيام في ذلك". فتح الباري 255/25 النوري 20ن

${ }^{42}$ Majmu’ Fatawa Syikh Ibn Bazz, Http://Fatawapedia.Com

43 Ibn Hajar Al Atsqalani, Fathul Bari Syarbu Sabih Al Bukhari, Jilid 8, Hal. 13 
Perihal kudeta seperti ini seringkali berhujung pada madharat dan tertumpahnya darah kaum muslimin yang sangat besar. Hal itu karena upaya kudeta tidak benar-benar dilakukan dengan perhitungan yang matang. Gerakan seporadis dan parsial seringkali mudah dipatahkan dan tidak lama kemudian hilang dari peredaran. Akibatnya, kaum muslimin lainnya menjadi sasaran empuk bagi kekuatan kuffar untuk ditindas jauh lebih buruk dari sebelumnya.

\section{KESIMPULAN}

Dari hasil bacaan yang penulis lakukan terkait fakta kehidupan minoritas muslim di negeri non muslim maka dapat disimpulkan sebagai berikut;

Pertama. Kondisi kaum muslimin di negeri eropa dan sejenisnya membutuhkan penjelasan fiqih yang tidak kaku namun tetap dikembalikan kepada tuntunan syari'at yang telah Allah turunkan kepada umat manusia. Jadi, manusia yang harus menyesuaikan diri dengan nash, bukan sebaliknya. Sehingga fatwa-fatwa yang keluar dalam fiqih aqalliyah dapat dipertanggungjawabkan.

Kedua. Sikap kelompok minoritas kepada penguasa adalah kooperatif, adaptif, solutif, dan inspiratif. Selama tidak bertentangan dengan ketaatan kepada Allah dan Rasulnya

Ketiga. Bersikap sabar, tidak emosional, mengedepankan dialog, dan senantiasa berkoordinasi dengan organisasi muslim yang ada jika terjadi tekanan, paksaan, dan beragam kesulitan interaksi lainnya.

\section{DAFTAR PUSTAKA}

Adlan, Athiyah, Fi Mas'alah Al Khuruj 'Ala Al Hukkam, Istambul: Ma'had Al Mishriyyah $\mathrm{Li}$ Dirasat As Siyasiyah Wa Istratijiyyah, 2017

Al Atsqalani, Ahmad Bin Ali Bin Hajar, Fathul Bari Syarah Sabih Al Bukhari, Beirut: Darul Ma'rifah, 1379

Al Bayanuni, Muhammad Abu Al Fatah, Al Madkhal Ila Ilmi Ad Da'wah, Damaskus: Mu'assasah Ar Risalah, 2014

Al Maqdisi, Ibn Muflih, Al Adab As Syar'iyyah, Tahqiqh: Syu'aib Al Arnauth, Beirut: Mu'assasah Al Rislah, 1999 
Al Muhsin, Abdullah Bin Shalih, Abadits Arba'in An Nawawiyah Ma'a Ma Zaada 'Alaiba Ibn Rajab, Madinah: Al Jami'ah Al Islamiyah, 1984

As Sa'di, Abdurrahman Bin Nashir Bin Abdullah, Taisir Karim Ar Rabman Fi Tafsir Kalam Al Mannan, Riyadh: Muassasaah Ar Rislah, 2000

As Syahri, Mulfi Bin Hasan, Haqiqatu Darain; Darul Islam Wa Darul Kufr, Abha Saudi Arabia: Dar Al Murabihtin, 2010

As Syuwailim, Muhammad Bin Muhammad, As Sirah An Nabawiyah Fi Dhau'i AlQur'an Wa As Sunnah, Damaskus: Dar Al Qalam, 1427

At Tahir, Hamid Ahmad, Sabih Qashash Al Qur'an, Terj. Umar Mujtahid, Jakarta: Pustaka Ummul Qura', 2019

At Thabari, Abu Ja'far, Jami' Al Bayan Fi Ta'wil Al Qur'an, Tahqiq: Ahmad Syakir, Ryadh: Mu'assasah Ar Risalah, 2000

Hazim, Ahmad Farid Shaliih Abu, Manhaj Al Qur'an Al Karim Fi Tadarruj Wa Atsarubu Fi Tagbyir, Universitas Utsman Qabus, Oman, Jurnal As Syari'ah Wa Dirasah Islamiyyah, September 2017

Hidayat, Surahman, At Ta'ayis Baina Al Muslimin Wa Ghairibim Dakbila Daulatin Wabidah, Mesir: Dar As Salam, 2001

Ibrahim, Muhammad yusri bin, Fiqbu Nawazil, Lil Aqalliyat Al Muslimab; Ta'sbilan Wa Tatbbiqan, Qathar: Wizarah Awqaf Wa Su'un Al Islamiyyah, 2013, Jilid 1

Katsir, Abi Al Fida' Isma'il Bin, Qashash Al Anbiya', Tahqiq: Abu Suhaib Muhammad Bin Samih, Mesir: Dar Ibnul Jauzi, 2005

Katsir, Abi Al Fida', Ibn As Sirah An Nabawiyah Min Al Bidayah Wa An Nibayah, Beirut: Dar Al Ma'rifah, 1976

Wanis, 'Ali Muhammad, Hukmu Iqmah Fi Bilad Al Kuffar, Saudi Arabia: Markaz Tsabit Lil Buhuts Wa Dirasat: 2016

Zaenuddin, Jeje, Metode Strategi Penerapan Syari'at Islam Di Indonesia, Jakarta: Penerbit Miumi, \& Pembela Islam, 2015

Zaidan, Abdul Karim, Abkam Adrimmiyyin Wa Al Musta'minin Fi Dar Al Islam, Beirut: Mu'assasah Ar Risalah, 1982 


\section{Dari Jurnal :}

Agus Setiawan, Perkembangan Lobi Yabudi Dan Pengarubnya Terhadap Politik Luar Negeri Dan Kongres Amerika Serikat, Jurnal Wacana, Vol. 6 No. 2, Oktober 2004

Umihani, Problematika Mayoritas Dan Minoritas Dalam Interaksi Sosial Antar Umat Beragama, Jurnal Tazkiyya, Iain Syekh Nurjati Cirebon, V. 20, N. 02, 2019, Hal. 249.

Moh. Zeinudin, Minoritas Muslim Di Barat (Studi Atas Pemikiran Tariq Ramadan), Esensia Vol Xii No. 1 Januari 2011, Universitas Wiraraja Sumenep Madura

Andi Rahman, Relasi Antara Muslim Dengan Non Muslim, Jurnal Kordinat Vol. Xv No. 2 Oktober 2016

Tharif Khadr Sulaiman, Al Qismah Al Tsana'iyyah Li Dar Baina Al Mujiz Wa Al Mani', Jurnal Tarbiyah Al Asasiyyah, Vol. 10, No. 1

Fiki Nuafi Qurrota Aini, Fiqih Minoritas, Http://IfPasca.Walisongo.Ac.Id/, Mengutip Mubasirun, "Persoalan Dilematis Muslim Minoritas Dan Solusinya” Episteme, Vol.10, No.1, Juni 2015

Dedi Sahputra Napitupulu Dan Syawal Fahmi, Pendidikan Islam Muslim Minoritas Jurnal Pendidikan Islam, Iain Curup, Vol. 5, No. 01, 2020

Bahrul Hayat, "Kontribusi Islam Terbadap Masa Depan Peradaban Islam Di Asia Tenggara", Dalam Jurnal Miqot, Vol. Xxxiv, No. 1, JanuariJuni (2012)

Nurhayati, Fikih Minoritas: Suatu Kajian Teoretis, Jurnal Ahkam, Uin Jakarta, Vol. Xiii, No. 2, Juli 2013

Imam Ahmad Mawardi, Fiqih Mayoritas Versus Fiqih Minoritas, Jurnal Justicia Islamica, Vo. 9. No. 2, Desember 2012

\section{Website :}

Https://Www.Pewresearch.Org/Fact-

Tank/2017/04/05/Christians-Remain-Worlds-Largest-Religious-

Group-But-They-Are-Declining-In-Europe/

Https://Republika.Co.Id/Berita/Qh7npm320/Jumlah-MuslimEropaamerika-Serikat-Naik-Ini

Https://Www.Bbc.Com/Indonesia/Dunia-54630462 
Https://Republika.Co.Id/Berita/Dunia-Islam/IslamNusantara/17/03/15/Omu55u328-Turki-Kritik-Larangan-Jilbab-DiEropa

Https://Padangkita.Com/Ini-Sosok-Perempuan-Yang-JadiWalikota-Muslim-Pertama-Di-Inggris/

Https://Www.Brilio.Net/Global/-Kisah-3-Pria-Muslim-JadiWali-Kota-Di-Kota-Berpengaruh-Dunia-Barat-170616o.Html

Https://Www.Voaindonesia.Com/A/Saud-Anwar-WalikotaMuslim-Di-Amerika/3341118.Html

Https://Www.Al-Qaradawi.Net/Node/4160 